\title{
CARING FOR THE SICK POOR IN ST BARTHOLOMEW'S EXCHANGE: 1580-1676
}

\author{
Andrew Wear
}

The first part of this essay looks at the care of the sick poor in one small London parish, St Bartholomew's Exchange (see map, figure 1), between the 1580s and the 1670 s. The second part puts some question-marks around the interpretation that I give to the parish material. The care of the sick poor appears to have analogies with the later care of the sick poor in hospitals, but in the second part I argue on structural, if not on socio-historical, grounds that a case can be made for seeing elements common to both the care of the poor, dependent sick and that of the well-to-do, independent sick.

St Bartholomew-the-Little, or St Bartholomew's Exchange as it came to be known, was a wealthy London parish traversed by Throgmorton Street and Threadneedle Street. It was $4 \cdot 1$ acres in area, which was on the low side for London. ${ }^{1}$ Figure 2 shows that in 1579, 86 houses were rated to pay for the clerk's wages. In the seventeenth century the number of houses rated gradually rose, but then fell disastrously to three after the Great Fire. Rebuilding quickly made up the numbers. ${ }^{2}$

The affairs of the parish were reported in the Vestry Minute Books and the Account Books. ${ }^{3}$ They disclose a world centred around the church, its upkeep, the selection and payment of its officials, and the care of the investments and property that originally had come to it in the form of charitable gifts and bequests. The books were written by the churchwardens, who also noted the other business of the parish, the

Andrew Wear, PhD, Wellcome Institute for the History of Medicine, 183 Euston Road, London NW1 2BN

\footnotetext{
${ }^{1}$ Roger Finlay, Population and metropolis, Cambridge University Press, 1981, 168. St Bartholomew's was quite respectable for size, if one excludes London's outlying districts.

2 The figures are taken from Edwin Freshfield (ed.), The Vestry Minute Books of the parish of St Bartholomew Exchange in the City of London 1567-1676, 2 vols, London, privately printed, Rixon \& Arnold, 1890; vol. 1: pp. 7-8, 18-19, 36-7, 48-9, 59-60, 74-5, 86-7, 103-4,131; vol. 2: pp. 3, 35, 53-4, 76-7, 96-7, 102, 110-11 (hereafter cited as Vestry Minute Books). Shops have been excluded, as have houses with no named inhabitants. The figure for 1732 comes from Freshfield's 'Introduction', p.vi. Apart from 1732, the figures are for houses rated for purposes such as payment for the sexton's, raker/scavenger's wages, for which all the parish including the poor were likely to be rated. Figures taken from the rates for the poor naturally do not include the poor and are less than the other figures. For instance, in 1579, 86 houses were rated for the clerk's wages and 55 for the poor; in 1630, 91 were rated for the sexton's wages and 74 for the poor.

${ }^{3}$ Ibid.; and Edwin Freshfield (ed.), The Account Books of the parish of St Bartholomew' Exchange in the City of London 1596-1698, London, privately printed, Rixon \& Arnold, 1895. (Hereafter cited as Account Books.) Many similar books survive for the other London parishes.
} 


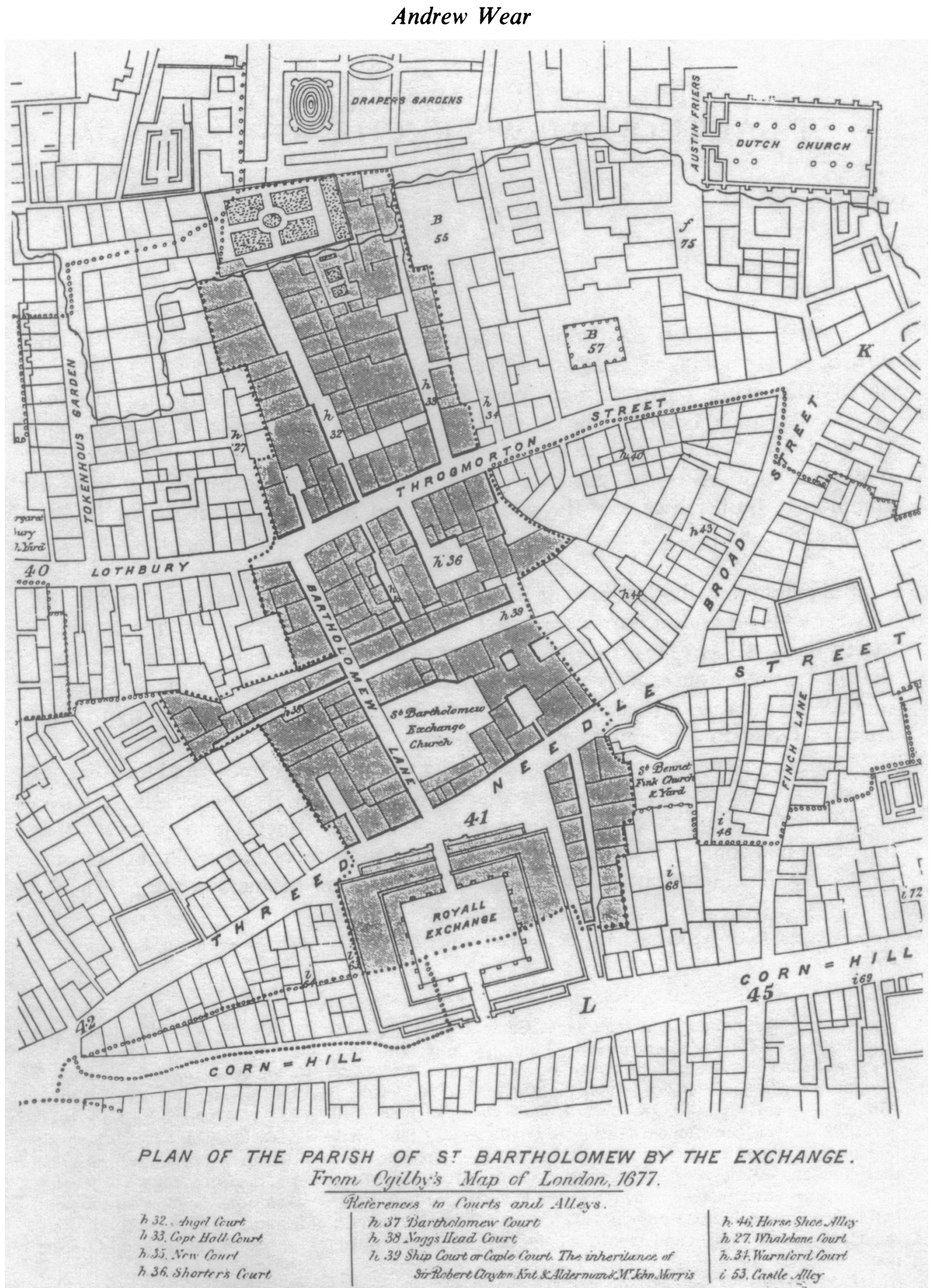

Figure 1. Parish of St Bartholomew by the Exchange. Reproduced from Edwin Freshfield (ed.), The Vestry Minute Books of the parish of St Bartholomew Exchange . . 1567-1676, London, 1890. 


\section{The sick poor in St Bartholomew's Exchange}

ordering and care of vagrants and the poor. Even though poor relief had been partly secularized, as the State attempted to produce at the beginning of the seventeenth century a uniform system of poor relief by means of legislation, the care of the poor remained a church matter as in the days of voluntary relief. ${ }^{4}$ The Vestry and Account Books detail the assessment of parishioners for poor relief and give the names of those parishioners who received pensions and relief in money or in kind and the amounts involved. There are also brief minutes of the discussions amongst congregation and officials concerning particular cases. Money spent on emergencies, for instance the medical expenses of parish pensioners, was noted down. The books also detail decisions and expenses concerning the disposal of vagrants, the care of out-of-parish women who gave birth, and the care and education of foundlings. In all, they give us an insight into the little world of the parish, a world that in terms of its organization, finance, and control over people was far more significant than its counterpart today.

The parish had a regular income from legacies, though most of the costs of poor relief were drawn from rates on householders. In terms of other London parishes, St Bartholomew's must have been well-off, as by the middle of the seventeenth century it was contributing money, on the Lord Mayor's orders, towards poor relief in other parishes such as Aldgate and Bishopsgate Without. ${ }^{5}$

The parish supported (that is, gave a weekly sum to) a maximum of around twelve pensioners, whilst there was a fluctuating group of poor numbering about twenty or less that included pensioners, which received bread, cheese, sea-coal, and money at different times, usually as the result of an annual disbursement of a legacy or as a one-off gift. The parish also had to look after foundlings, who were often "nursed" (the term includes the care of older children) outside in places such as Ware and Walthamstow. The numbers again were very small, below ten, but the foundlings constituted a heavy burden when seen as a proportion of the poor account. In 1634-35 the amount expended on the poor came to $£ 73.4 \mathrm{~s}$. $10 \mathrm{~d}$., of which $£ 39.0 \mathrm{~s} .10 \mathrm{~d}$. was spent on foundlings and $£ 34.4 \mathrm{~s} .0 \mathrm{~d}$. in various ways on the poor. In detail, the parish gave nine parishioners pensions totalling $£ 12.18 \mathrm{~s} .4 \mathrm{~d}$. for the year; $£ 5.15 \mathrm{~s} .8 \mathrm{~d}$. worth of sea-coal, $£ 5.4 \mathrm{~s} .0 \mathrm{~d}$. of cheese (partly given in money), and $£ 6.10 \mathrm{~s} .0 \mathrm{~d}$. of bread were distributed to the poor; expenses concerning the Beadle and the Overseers of the Poor and to do with the poor-rate came to 8 shillings. Other sums spent on the poor were $£ 1.8 s$. for releasing the parish pensioner Widow Empson from prison, and $£ 2$ for the lodging of another pensioner, Peter Hartly, whose father had left money to the

\footnotetext{
${ }^{4}$ On poor relief see E. M. Leonard, The early history of English poor relief, Cambridge University Press, 1900; E. M. Hampson, The treatment of poverty in Cambridgeshire 1597-1834, Cambridge University Press, 1934; Geoffrey W. Oxley, Poor relief in England and Wales 1601-1834, Newton Abbot, David \& Charles, 1974. Long after this paper was written, the standard work on the subject was published: Paul Slack, Poverty and policy in Tudor and Stuart England, London, Longman, 1988. For a European perspective, see Brian Pullan, Rich and poor in Renaissance Venice, Oxford, Basil Blackwell, 1971. For detailed micro-studies that focus on the poor themselves, see Paul Slack, 'Poverty and politics in Salisbury 1597-1666', in Peter Clark and Paul Slack (eds), Crisis and order in English towns 1500-1700, London, Routledge \& Kegan Paul, 1972, 164-203; the essays by Tim Wales, 'Poverty, poor relief and the life-cycle: some evidence from seventeenth-century Norfolk', and W. Newman Smith, 'The receipt of poor relief and family situation: Aldenham, Hertfordshire 1630-90', both in Richard M. Smith (ed.), Land, kinship and life-cycle, Cambridge University Press, 1984, pp. 351-404 and 405-20 respectively.

5 Account Books, 141, 173.
} 


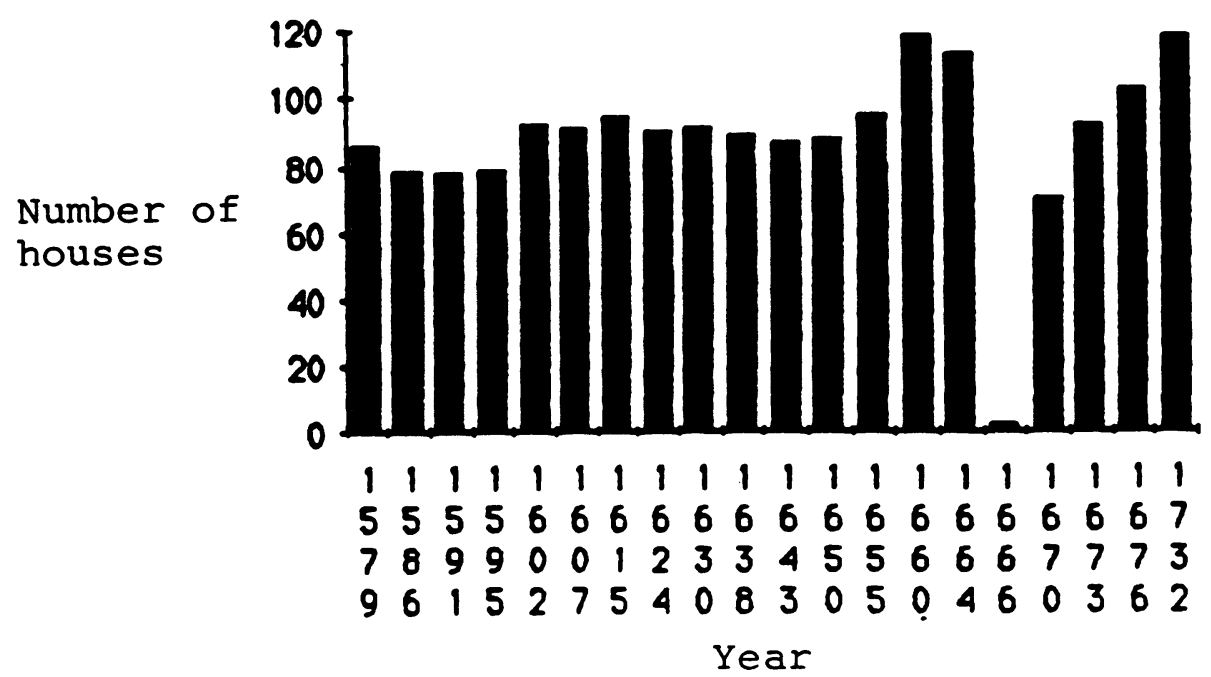

Figure 2. Houses rated for scavenger's wages, etc.

parish for his care. When the newborn foundling Mary Throgmorton was discovered, the parish laid out a total of $£ 3.15 \mathrm{~s} .2 \mathrm{~d}$. for her nursing for twenty-eight weeks until her death, christening, clothing, and the search for her mother; Goody Hasard, one of the parish pensioners, was given $\mathfrak{f 6 . 4 s}$. for nursing and clothing Sara Potts for a year; and £26.11s.8d. was spent on the care, clothing, travel, and schooling of five other foundlings nursed outside the parish. Foundlings were often apprenticed, and in 1634-35 the parish paid out $£ 2.10 s$. for the apprenticing of Mercie Bartholomewlane. ${ }^{6}$

These figures are reasonably typical, if on the low side. In the Cromwellian period the amount spent on the poor in St Bartholomew's increased. In 1657-58, when the parish was receiving more money from a generous legacy and from property rents, £139.19s.11 . was spent on the poor account. ${ }^{7}$ The numbers of the poor are small and it is not worth spending too long putting them into any statistical form. The advantage, however, of having the record of a small number of poor in one place over a long period of time is that one can go down to the level of individuals and study their interactions and careers.

Help to the individual was governed by the system of parish provision for the poor set up by the 1597-98 and 1601 Poor Law Acts. The two churchwardens and the two to four overseers of the poor drawn from "substantial householders" of the parish, ${ }^{8}$ together with the system of assessing a rate for poor relief from the parish

\footnotetext{
${ }^{6}$ Ibid., 98-9. See also Valerie Fildes, 'The infant wet-nurse and her role in infant care, 1538-1800', Med. Hist., 1988, 32: 142-73.

${ }^{7}$ Account Books, 160-1. This excludes the sum of $£ 100$ lent to the Grocers' Company and included in the accounts under money paid on the poor account.

8 John Pound, Poverty and vagrancy in Tudor England, Harlow, Longman, 1971, 106; who prints an excerpt from the Poor Law of 1601 (Statutes of the Realm, vol. 4, pt. 2, pp. 962-5).
} 
householders, ensured that in a small parish there continued to be the same intimate connection between donor and recipient as when contributions were voluntary. ${ }^{9}$ This connection was given visible expression when the poor were forced to give public thanks for the parish's charity. At a Vestry meeting in 1582:

The most of the parishioners being assembled it was ordered and agreed that for all such bread as is given and distributed to the poor every Sunday in this parish Church, that the said poor immediately after the epistle and gospel every Sunday shall come up into the chauncell and there give the Lord thanks for his blessings bestowed upon them and for such of the said poor as will not come in form afore said it shall be at the liberty and discretion of the church warden for the time being to give and bestow their bread to the poor present. ${ }^{10}$

In $1627-28$, the parish paid $5 s .10 d$. for " 9 Tickets [or labels] of pewter with the letter $P$, and the name of the Pensioners to wear". ${ }^{11}$

The public labelling of the pensioners gives us a clue to their relationship to the parish. They belonged, quite literally, to the parish, and when they died their possessions became parish property. Their pensions were granted "with this caution that they and everyone of them behave themselves well and orderly and be always ready to perform their best service to every inhabitant of this parish". ${ }^{12}$ However, the relationship between parish and pensioner was not simply coercive or degrading. After all, it was concerned with charity and there was apparently a good deal of benevolence. It is on this mixture of benevolence and coercion and its various forms that I shall concentrate.

\section{THE SICK POOR}

The general position of the poor outlined above helps us to understand how the sick poor in St Bartholomew's were looked after. ${ }^{13}$ Sickness was one of the characteristics that helped to define the status of a poor person in the eyes of the parish authorities and to determine their response. Many of the poor receiving pensions from the parish were likely to be, or to fall, sick.

In 1600 , the twelve pensioners were described as "being past labour and very poor, allowed pensions". Most were widows, or men with many children, and in the demographic terms of the time all were very, very, old:

\footnotetext{
${ }^{9}$ Ordinances and laws that made contributions to the poor compulsory came in fits and starts. London levied a compulsory poor rate in 1547; Norwich, more successfully, in 1570; and the government in 1572.

10 Vestry Minute Books, vol. 1: 14.

11 Account Books, 75. Beggars and vagrants had been "badged" by the authorities from 1514 in London: Leonard, op. cit., note 4 above, 25-6. In 1600, recipients of pensions in London were ordered that they "shall every day openly wear a badge upon their left sleeve"-refusal merited suspension of relief: A. L. Beier, Masterless men: the vagrancy problem in England 1560-1640, London, Methuen, 1985, 155.

12 Vestry Minute Books, vol. 1: 56 (1607).

${ }^{13}$ On the sick poor see, as well as the works cited in note 4, Margaret Pelling 'Healing the sick poor: social policy and disability in Norwich 1550-1640', Med. Hist., 1985, 29: 115-37; Thomas R. Forbes, Chronicle from Aldgate: life and death in Shakespeare's London, New Haven, Conn., Yale University Press, 1971.
} 
Phillip Williamson and his wife, aged either of them 80 years

Weekly pension and very poor

Widow Atkinson, bedrid, extreme poor

Widow Hall, aged 70 years, very poor

$6 \mathrm{~d}$

Widow Preston, aged 70 years and very poor

$7 d$

Widow Sherbrooke, aged 70 years and very poor

$7 d$

$7 d$

John Rankyn, aged 85 years, with wife and many children, very poor

Widow Boothe, aged 70 years, past labour, and very poor

Widow Wood aged 80 years and very poor

Widow Cuttings, aged 80 years and very poor

John Saunders, aged 66, poor and many children

Clearly people of this age group would more often fall ill and need help. For instance, Goodwife Hall (listed above) was given a total of twenty-five shillings "in her sickness" between 15 July and 23 November 1599 , over five different occasions. ${ }^{15}$ As the parish became accustomed to the new poor law, the pensioners may have been chosen at an earlier age, as many of them were pensioners for quite long periods. However, they remained mainly widows, men incapable of supporting families, or people totally incapable of working.

There was a two-fold system of health care for the parish poor. One was run by the pensioners themselves; the other had recourse to "official" medicine in the form of seeking out and paying for the advice and remedies of surgeons, physicians or apothecaries. The parish gave special sums in addition to the pensions and hand-outs, to give access to both systems. In the parish's health system there were appointed, from the ranks of the pensioners and the poor, "keepers of the sick" as well as "searchers" who would certify cause of death and "searchers of the sick suspected" (that is, of having plague). ${ }^{16}$ The system was in existence early on. In 1577 (a plague year), "It was ordered that these women ... receiving the alms of the parish ... being able upon request shall keep any sick person that shall happen within the parish of what desease soever it be, upon pain to lose the alms to them refusing given."17

This threat was not an empty one, for in 1582 the Vestry meeting agreed that those "nominated to be keepers of sick folks and such as be visited with the plague" should get more than the ordinary poor: "in all distributions not only so much as any other in the parish but also shall have each of them as much more, as well in bread every Sunday as in coals and money given out of the church box." Those serving the parish got " $4 \mathrm{~d}$ for a day and $4 \mathrm{~d}$ for a night and meat and drink, to be paid by them that shall have need of them". However, the carrot was not enough and the minutes list five widows who refused to keep sick persons with the result that "they shall have no relief by the said parish neither in bread, coales nor in money as they were wont, but the same to be distributed where more need is". ${ }^{18}$ In the end, most of the women agreed to be searchers or keepers of the sick.

${ }^{14}$ Account Books, 8.

15 Ibid.

16 Vestry Minute Books, vol. 1: 5, 13, 27.

${ }^{17}$ Ibid., 5.

18 Ibid., 13. 
This was the only example in the St Bartholomew's records of relief being refused to those who did not agree to look after the sick or to be searchers. ${ }^{19}$ In fact, it paid the poor to help the parish authorities. Sometimes they would be given money to look after foundlings before they were put to nurse, or a widow might nurse one on a long-term basis herself. Although a pension might be lowered to take account of the extra income, in general it seems that it was profitable for a pensioner to help the parish. (One difficulty in calculating how much a poor person was earning is that any income from such outside sources as tailoring or laundry-work is unknown: parishes often seem to have supplemented earned income and, as the person grew less able to work, the amount given by the parish increased. ${ }^{20}$ Widow Hasard, one of the two searchers in the 1630s (the official posts of keepers of the sick seem to have lapsed), made $£ 5.4 s$, in 1635 , in addition to a yearly pension of $£ 1.6 s$., for looking after Sarah Potts. ${ }^{21} \mathrm{~A}$ shilling a week early in the seventeenth century and a bit over a shilling in the second half of the century might have been just sufficient to live on, though some contemporaries thought not. ${ }^{22}$ Between 1633 and 1648, Widow Hasard got a regular income for looking after Sarah. For instance, in 1643-44 the parish "paid widow Hasard for clothing Sarah Potts 20/-, for her boarding and schooling $£ 4.19 s .8 d$. at $23 d$. per week, $£ 5.19 s .8 d . " 23$ (The pensioners also helped at the christening of foundlings, and for this, significantly, they were also paid-an early example of good deeds being put on a commercial, contract basis.)

The system of parish welfare was of mutual benefit to the parish and the parish poor. It is in this context that the sick were cared for. Widow Hasard was paid a total of one pound "at several times from the 17 of August to the 2 of October 1640 for Peter Hartly when his leg was broke". ${ }^{24}$ Evidence of the poor looking after their own for a price is present for the whole of the period. In 1602, Goodwife Wharleton, who was poor but not in absolute poverty, was paid $2 s .6 \mathrm{~d}$. a week to look after

\begin{abstract}
Ann Smith a poor maid born in this parish of age 27 years the daughter of John Smith sometime Sexton of this parish deseased which poor maid [is] alleged to be lame and sickly praying to be releaved by the parish which was yielded unto. Viz, that the Church wardens should provide her of her apparell, diet and lodging, till she recovered health and strength to get her living by her own service and labour at the charge of the parish. ${ }^{25}$
\end{abstract}

This may have been a special case, for the poor were usually enlisted in caring for the sick in cases of old age, often in the days before death, and of chronic ill health.

\footnotetext{
${ }^{19}$ In 1581, the Lord Mayor ordered that, if the viewers gave the wrong certificate or refused to serve, they should be imprisoned. Thomas R. Forbes, 'The searchers', in Saul Jarcho (ed.), Essays on the history of medicine, New York, Science History Publications, 1976, 148-9.

${ }^{20}$ On this, see Wales, op. cit., note 4 above.

21 Vestry Minute Books, vol. 1: 124.

22 Keith Wrightson and David Levine, Poverty and piety in an English village: Terling, 1525-1700, London, Academic Press, 1979, 40-2. Gregory King calculated the income of a pauper family as $£ 6.10$ s. per annum: Peter Laslett, The world we have lost-further explored, London, Methuen, 1983, 32-3; Wales, op. cit., note 4 above, 356-7; Keith Wrightson, English society 1580-1680, London, Hutchinson, 1982, 32-4.

${ }^{23}$ Account Books, 123.

24 Ibid., 116.

${ }^{25}$ Ibid., 20; Vestry Minute Books, vol. 1: 47.
} 
The Vestry and the overseers of the poor seem to have been flexible in their response to the needs of the poor, and sickness was the most frequent reason for temporary increases in pensions or for extra payments to cover the expenses of illness. The accounts for 1602 note, "paid to goodwife Garladye for a benevolence in time of her childrens sickness, which was taken out the poor's money in the chest... $£ 1-00-00 "{ }^{26}$ Frequently, help was slow in coming, the parishioner being made absolutely penniless first, as when "old John Griffin's daughter" got some allowance "towards the reclaiming of her apparell which she was constrained to pawn in the time of her sickness". 27

The example of Widow Bulling and her daughter-in-law, Mary Bulling, illustrates the relationship between the patient, the carer, and the paymaster. Widow Bulling had been a searcher and pensioner, together with Widow Hasard. Mary Bulling was not a pensioner, but one of the poor who received bread and coal. In 1659, Widow Bulling got an additional five shillings a week on top of her pension of two shillings a month: "upon consideration of the great age and decrepitude of the widow Bulling then bedrid". Mary Bulling "desired 3/- per week to look to her" but the Vestry decided "she should have but two shillings six pence per week". ${ }^{28}$ Mary looked after her for twenty-seven weeks. When her mother-in-law died, Mary "desired the parish would give her those few old things her mother left behind her. Twas agreed. In regard of the readiness of Mary Bulling to serve the parish upon occasions, that she should have them."29

And Mary Bulling did serve the parish, as, for instance, in 1661, when "Elizabeth Southern, a woman having no habitation" gave birth: the parish provided food, fire, straw, and "the nurse", who was Mary Bulling, "to tend her till she was able to go away". Mary got nine shillings for "tending her and cleaning the house", with the rest of the poor also joining in "the bread and beer", which cost seven shillings, for "the pensioners and company" at the child's funeral. ${ }^{30}$ Mary's career repeated that of her mother-in-law. She became a searcher and, like Widow Bulling, got extra money from the parish just before she died.

Two points can be made from the example of the Bullings. First, the parish did pay proportionately much larger sums to people who were so ill and aged that death was probable, and who certainly stood no chance of being made well enough to work (as in the case of Ann Smith). This is rather different from the practice in Norwich, where relief to the sick poor appears to have been tied to the aim of getting people back to work. ${ }^{31}$ Second, the payment to Mary Bulling and to other poor people for looking after each other says something about the ideology of neighbourly and family help which was so prevalent in early modern England. Even a relative ${ }^{32}$ could expect, and received, payment for looking after someone who was ill. If the seventeenth century

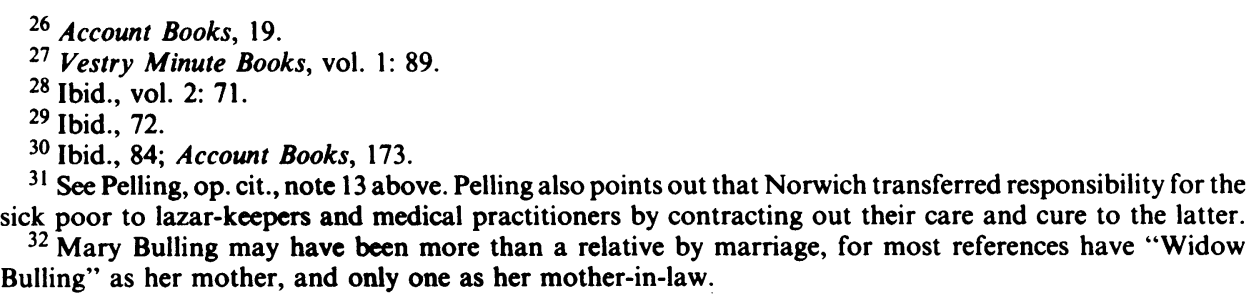


saw the rise of capitalism, then here is perhaps a small example of the process: the ideals of voluntary mutual care being transformed into a financial arrangement-a transformation not yet complete, as is shown by the present debate as to whether the State should pay women to care for their mothers.

It may be that the system that I have briefly illustrated-of the poor being paid to help each other-was one that was cheaper than other alternatives, such as bringing in help from medical experts. However, the parish did pay for medicines and for the cost of surgeons and apothecaries. We may be on safer ground to talk of the poor providing nursing care rather than medical help, as the records do not say precisely what kind of help was given (though the boundary between nursing and medical care must have been very blurred, and the seventeenth-century practices of lay and family medical care amongst the middling classes ${ }^{33}$ would lead one to the conclusion that medical care as well as nursing was given).

The moral ideal of family and neighbourly care found in books of practical divinity $^{34}$ and in practice in actual examples (seen especially in childbirth) ${ }^{35}$ does not appear to have been invoked by the parish authorities in an attempt to get health care on the cheap. This may be partly due to the types of poor involved, who were often aged and without family. Yet the parish, after it was bequeathed some houses in 1643, housed its poor in one small area, many of them in one house; ${ }^{36}$ and with its coercive powers it could have forced them to look after one another without payment (as the Geffrye almhouses did at the beginning of the eighteenth century) ${ }^{37}$ — perhaps using the ideal of neighbourly love to justify its doing so-but it did not take that option. The frequency of the examples of the poor being paid to look after the poor means that care of the sick and dying even outside the regular medical context-for instance, when Widow Hasard was dying, her "daughter" Sarah was paid two shillings for washing her linen ${ }^{38}$ _was viewed as a commercial matter.

\footnotetext{
${ }^{33}$ On this, see the essays in Roy Porter (ed.), Patients and practitioners, Cambridge University Press, 1985.

34 The works of the early seventeenth-century theologian, William Perkins, are full of practical divinity, as is William Gouge's Of domesticall duties, London, 1622. For discussions of practical divinity, see William Haller, The rise of Puritanism, New York, Harper Torchbooks, 1957, 22-6; C. Hill, Society and Puritanism in pre-revolutionary England, London, Secker \& Warburg, 1964, 443-81; John Morgan, Godly learning: Puritan attitudes towards reason, learning and education 1560-1640, Cambridge University Press, 1986, 142-71.

${ }^{35}$ See Adrian Wilson, 'Participant or patient? Seventeenth-century childbirth from the mother's point of view', in Porter (ed.), op. cit., note 33 above.

${ }^{36}$ In 1652, the vestry minutes note: "ordered that the poor people that are pentioners to the parish shall go to the general rooms following in Dibles Alley. Margaret Racy and Ann Wheeler in the first room, widow Hasard in the second room upward, goody Tedder in the 3 room upward. At the same vestry agreed with Mrs. Fox to give her £5-10-00 a year for one year . . f for a little house in Dibles Alley. At the same vestry agreed and ordered that Mrs. Chandler shall have the upper chamber and the garret of that house, Goody Shory to have the lower chamber and the use of the kitchen in common between her and Mrs. Chandler". Vestry Minute Books, vol. 2: 20.

${ }^{37}$ Rule 25 of the almhouses stated: "That none of the almspeople shall refuse to be aiding and assisting one another; and in case of sickness, 'tis expected they shall, by turns attend, assist and be helpful to each other, and live in peace and unity with each other: and which of them shall refuse their good offices to another in sickness, shall, upon good proof be expelled the house". Neil Burton, The Geffrye almshouses, London, Geffrye Museum, 1979. I am grateful to Mr H. J. M. Symons of the Wellcome Institute Library for the reference. The analogy between parish and almshouse care of the sick may well be worth exploring.

38 Account Books, 184
} 
The second type of health care system to which the poor and the parish had recourse was the familiar one provided by apothecaries, surgeons, and physicians. The foundlings often needed medicines and expert attention. In 1638, Widow Hasard was given ten shillings "to pay Mrs. Tedman for the Cure of Sarah Potts and for a powder", Hercules Wilson got 2s.6d. "that he laid out for physic for the child Mary Bartholomewlane when she was sick", and in 1639 the orphan Thomas Baldwin had seven shillings laid out for the "healing of [his] ... head". 39 The pensioners often petitioned for their medical bills to be paid. In 1631, Bridget Harris's daughter was "under the surgeon's hand", and it was certified to the Vestry "that the widow Harris had one of her daughters that hath a lame hand in danger to loose it which had cost her much money above her ability and was thereby come into debt towards whose relief it was ordered [the churchwarden] should pay her four pounds."40 In 1633, "Widow Varnham's [a pensioner] petition was read desiring some relief towards her great necessity, by reason of her sickness and a great grief with a sore leg which cost her a great deal of money and was not yet well recovered". The churchwarden was ordered to give her twenty shillings. ${ }^{41}$ Widow Tame, another pensioner, was reported in 1643 by the churchwarden to the Vestry as "being in a course of physic, desired to have their further help and was thankful to their former charity to her". The churchwarden was ordered not to see her in want and gave "at several times to $\mathrm{Mr}$. Butler the apothecary for physic and to relieve her in her necessity $12-08-00$ ". 42 Three years later, in 1646, Widow Tame "being in great necessity" was given " 2 shillings a week for her maintenance and likewise to pay her surgeon for his care and recovery of her"; the total was $£ 2.2 s .6$. $^{43}$

There is little hint from the records that a system of wise women, or of local, non-"professional" expertise was being tapped, with the possible exception of the reference to Mrs Tedman. The very poorest members of the community availed themselves of expert help, and the parish authorities do not seem to have objected to their seeking out the expertise available in the medical market-place. Of course, a term such as "surgeon" could carry a multitude of meanings (as can be seen from the medical advertisements of the time) in a period where licensing was slack, and variety, rather than uniformity, in medical education and knowledge the norm. However, the records do not tell us if the parish poor paid for lay medical expertise (this is not suprising as lay medicine was often practised in the contexts of the family, or of charity).

The help given by the parish to pay for medical aid was not given automatically or as of right. The poor had to petition for it, they usually had to spend their own money first before trying to get it back, and they frequently had to be seen to be penniless and in debt before any money would be given. For instance, when Widow Tame in 1646 asked for help, she had already been given fourteen shillings to redeem the clothes that she had had to pawn. ${ }^{44}$

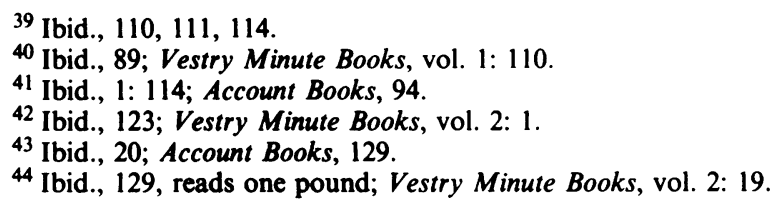




\section{The sick poor in St Bartholomew's Exchange}

The parish did not always pay the high cost of medical treatments. In 1659 Widow Hall, one of the pensioners, had an accident and the churchwarden wrote in the Vestry book:

I desire to know what they please to do about the great charge that had been disburst for widow Hall, who fell down her stairs and broke her arm and bruised her head and body ["bruised" in the seventeenth century had a much stronger sense than today], and what I should do with some moneys I found in her chamber which was sealed up by the overseers of the poor and left in my hands.

The lumping together of the high cost of treatment and the discovery of Widow Hall's money was no accident. Charles Younge, the churchwarden, continued:

Twas referred wholly to the overseers of the poor and they were also desired to mediate with Mr. Thicknes in her behalf who required $\mathrm{f} 6$ for her cure. And they accordingly did speak with him but he would not bate any thing, so they paid him that sum out of her money and gave her the rest which was about $£ 6$ more out of which she was to pay the apothecary and the other charges to be borne by the parish. ${ }^{45}$

Here the parish seems to be making the arrangements for treatment, though it is not certain if the initiative came from it or Widow Hall herself: in other cases the poor themselves seem to have decided to embark on the course of treatment.

Though the poor account for 1659 was large (it brought in $£ 302.19 s .8 d$., of which $£ 118.10 \mathrm{~s} .3 \mathrm{~d}$. was carried to it from the previous year, with $£ 168.04 \mathrm{~s} .9 \mathrm{~d}$. being spent during the year) six pounds and more was a tidy sum for the parish and it is not suprising that Widow Hall had to pay the medical costs out of her own money-in any case, this was inevitable given the legal prerequisite for poor relief, which was destitution. One wonders if Churchwarden Younge just happened to find the money or if he deliberately searched for it. In the event, the parish did spend ten shillings for Dr Daughtrey and $11 s .6 d$. for "necessaries"; it raised Widow Hall's pension for a number of weeks, paid her nurse $4 s .6 d$. a week for four weeks, $3 s$. for six weeks, and $12 d$. for three weeks, making in all $£ 1.17 s$; and gave Mary Bulling $5 s$. for "keeping her since". 46

What the parish paid for was a mixture of the two systems - of the parish poor caring for each other and of medicines and orthodox medical care. This, in fact, was the norm, especially when the case was protracted. From early on, the two systems were joined together. In 1598, the parish testified to the medicinal value of alcohol and "paid to the relief of a poore man which was fallen sick in the Royal Exchange about the 12 of January 1598, and for aqua vitae and 3 poor women to look to him, 20d."47

One way of illustrating the way in which the two systems ran side by side is to look at the case of Katharine Rumney, or Rumley. The related documents are summarized in the Appendix. Her father was a plasterer who did the occasional job for the parish. By 1647, he was a pensioner of the parish and both he and his wife, Goody Rumley,

${ }^{45}$ Ibid., 71.

46 Account Books, 166.

${ }^{47}$ Ibid., 6. 


\section{Andrew Wear}

received extra money when ill. The extracts from the Vestry Minute Books and the Account Books illustrate many themes already discussed: the extra payments for special needs and for care when death was imminent, relatives being paid to care for each other, the poor being paid for caring for one of their own, and the use of orthodox medicine. The case also illustrates what happened when one of the poor was taken to an institution. The sick poor in St Bartholomew's, even if very ill, normally were looked after in the parish. This was understandable, given the scarcity of hospitals and the model of the care of the sick within the family, which was favoured by the well-off. Katharine Rumney was one of the few exceptions, and was sent at different times to Bethlem, the only public institution for the mad in London, though there were private mad-houses that catered for those with money. A patient could stay at Bethlem for a maximum of one year, the charges to the parish were high, and Katharine Rumney's illness was probably episodic: in any case, she entered Bethlem several times and the parish seems to have taken extra care of her in the periods before she became a patient and after her discharge (see the Appendix). ${ }^{48}$

The care of the sick in the parish of St Bartholomew's seems so far to have been reasonably humane. But for those who did not belong to the parish, that is, who had not been born there or resident there for three years, the picture was far less rosy. The parish was often a fount of charity, whether, as in 1599 , giving $6 d$. "to a poor man which went to the Bath", paying ten shillings to "Dr. Crumton for his opinion about Mr. Webbe's stone", giving 8d. "to one which had been Mr. Mapledon's maid which was gotten with child" or, in 1614, paying two shillings "to two poore turkes turned Christians", ten shillings "to Mr. Parker his son being borne within this parish for his relief in his extremity", and giving four shillings "to two poor men who came by patent [special permit] for relief". 49 The parish could also respond collectively to other people's disasters, as in 1675-76 when eighty-four parishioners (most of the parish) contributed $£ 32.9 \mathrm{~s} .6 \mathrm{~d}$. "towards the relief of the poor inhabitants of the town of Northampton burnt out by the late dreadful fire". ${ }^{50}$ However, charity was either given to the parish's own, or to outsiders who were recognizably legitimate recipients. Those who were strangers to the parish and poor, if fit, would be whipped out of the parish. Those who were sick were kept in the parish cage, a covered pen, where only minimal care was given such as bales of straw for bedding. In St Bartholomew's, pregnant women were noted as being kept there, and many deaths occurred in the cages of other parishes. The sums laid out by St Bartholomew's on behalf of women in the cage were small: "paid to Mr. Knotsford per so much he laid upon a poor woman carried to the Cage, 5/3"; "Paid Ezekiell Cakebread for carriage of a woman in labour to the Cage, $12 \mathrm{~d}$., for straw 1/4, for relief $6 \mathrm{~d}$ ". 51 The Poor Laws, and custom, ensured that a sense of close-knit community existed between the parish and its poor. The frequent allusions to strange big-bellied women being moved out of the parish so that they did not become a charge upon it, and the refusal of relief to

\footnotetext{
${ }^{48}$ Not all of the monies paid to the Rumneys have been noted, my intention being to give a representative impression of the family's career as noted in the Account and Vestry books.

49 Account Books, 6, 49.

50 Vestry Minute Books, vol. 2: 128.

51 Account Books, 74, 108, (1626, 1637).
} 
petitioners born or resident outside the parish, must all have helped to produce a sense of exclusiveness and hence inclusiveness.

The description of the parish of St Bartholomew can give only a limited picture of how parish poor in general were looked after. The work of Tim Wales on Norfolk, Margaret Pelling on Norwich, and Thomas Forbes on London can broaden it, and clearly more detailed work on parishes in London and elsewhere has to be carried out.

\section{THE WIDER CONTEXT}

At one level, this account of St Bartholomew's and its poor can complement studies of hospitals of the time. The clientele were the same-poor-as was the emphasis on regulating their lives. The parish acted as a smaller version of the hospital, but kept the sick poor in the community. ${ }^{52}$

This is the gloomy picture of the care of the sick. It worsens if one notes how often the pensioners in St Bartholomew's followed in the footsteps of their fathers, mothers, (and adoptive mothers) or husbands and remained caught in the poverty trap of seventeenth-century London (for instance, the two pensioners for 1676, in the last entry in the Vestry Minute Book, are Sara Hasard and Susan Chandler, whose mothers had also been pensioners). However, there are one to two brighter spots-money was expended on the care of the sick poor in the parish, even if death was the likely prognosis (maybe not a bright spot, just the bottom line for care and charity). The poor were paid to look after their own, when they could have been forced to do so for nothing, as happened in almshouses and hospitals. Finally, I seem to detect a sense of neighbourliness or family care, but one in which the care is paid for.

The gloomy picture has become the standard view of hospital care and parish poor relief in the hands of Michel Foucault and other historians. We see the hospital emerging in the eighteenth and nineteenth centuries from its small-scale origins in the early modern period and before, to serve as part of a two-fold image. The hospitals with their captive poor are depicted as growing at the expense of the "good" image of illness in the family setting, where the patient was in familiar surroundings and free from the domination of institutions and of doctors. ${ }^{53}$ It may be that these contrasting pictures are both correct. But it would pay to be cautious. The contrast has been made between the eighteenth and ninteenth centuries and the period before, and between the hospital and the family. I am not convinced that enough is known about the seventeenth-century care of the sick in the family to be able to decide whether it really was a lost golden age-but that is another paper.

\footnotetext{
52 The hospitals took in a greater variety of people, but the emphasis on residential qualification, poverty, and the policing of virtue was of the same nature as in the parishes. See The Order of the Hospitals of King Henry the viiith and King Edward the vith viz St Batholomew's Christ [Hospital]. Bridewell. St Thomas's, London, 1557, pp. b7v, c6v-c7r, d1r-d2r, elr-elv. See also the Orders and ordinances for the better government of the Hospital of Bartholomew the Lesse ..., London, 1652.

${ }^{53}$ On this see Michel Foucault, The birth of the clinic: an archaeology of medical perception, trans. A. M. Sheridan, London, Tavistock, 1973; Erwin Ackerknecht, Medicine at the Paris Hospital 1794-1840, Baltimore, MD, Johns Hopkins University Press, 1967. For a different view of the rise of the middle-class hospital in the late nineteenth century, see Morris Vogel, The invention of the modern hospital, Chicago University Press, 1980.
} 
In the brief space left in this essay I shall look at sick people who were independent financially, as opposed to the dependent poor, and indicate that the same two systems of health care-lay and expert-were used, but in different ways, when independent, well-off people were ill. In other words, the structure of health care was analogous, if not the same in terms of quality, across the population.

The poor named in the records of St Bartholomew's remain silent. We do not know what they thought of the welfare provided by the parish, nor do we know what sort of care they gave each other-whether they made up medicines, performed medical procedures or whether they gave only simple nursing care.

The diaries, letters, autobiographies and other documents of the articulate, literate, population provide us with answers to these types of question and, of course, give a kind of history different from that which we can write about the poor. ${ }^{54}$ In well-to-do households a great deal of lay medical expertise was put into practice. Often the medical expert seems to have been largely absent, being consulted only in cases of very severe illness. For example, only on such occasions was a doctor brought in from Wigan to care for the Blundell family of Crosby, a journey of about twenty-five miles. William Blundell (1620-98) had recourse to a family recipe book in which visitors were invited to write useful remedies for illness. ${ }^{55}$ In his notebook he wrote:

The best cure for a flux of blood is suppositories made of the fat of bacon put up betwixt every stool till you find the effect which will be complete in two days. If the bacon be roasted it is rather better than otherwise. This was told me by my old friend Mr. Price, the Protestant Bishop of Kildare, who had good experience of it. ${ }^{56}$

There was clearly a traffic in favourite remedies in early modern England. John Donne wrote "some shall wrap pils, and save a friends life so". 57 Lord Edmund Howard, son of the Duke of Norfolk, wrote in the 1530s to the Lady Lisle:

Madame, so it is I have this night after midnight taken your medicine, for the which I heartily thank you, for it hath done me much good, and hath caused the stone to break, so that now I void much gravel. But for all that, your said medicine hath done me little honesty, for it made me piss my bed this night, for the which my wife hath sore beaten me, and saying it is children's parts to bepiss their bed. Ye hath made me such a pisser that I dare not this day go abroad, wherefore I beseech you to make mine excuse to my Lord and Master Treasurer. ${ }^{58}$

In 1538, Lord Lisle wrote to his wife that her "powder for the stone had saved two lives", 59 so the remedy-if it was the same-had good effect.

\footnotetext{
54 For this type of medical history, see the essays by Beier, Lane, and Wear in Porter (ed.), op. cit., note 33 above; and Andrew Wear, 'Interfaces: perceptions of health and illness in early modern England', in Roy Porter and Andrew Wear (eds), Problems and methods in the history of medicine, London, Croom Helm, 1987.

\$5 Margaret Blundell, Cavalier letters of William Blundell to his friends 1620-98, London, Longmans Green, 1933, 56-7.

${ }_{56}^{56}$ T. Ellison Gibson, A cavalier's note-book, London, Longmans, 1890, 193.

57 John Donne, 'Upon Mr. Thomas Coryat's crudities', in John Donne: complete poetry and selected prose, ed. John Hayward, London, Nonesuch Press, 1962, 141.

${ }_{58}$ Muriel St Clare Byrne (ed.), The Lisle letters, 6 vols, University of Chicago Press, 1981, vol. 2: 499-500.

59 Ibid., 500 .
} 


\section{The sick poor in St Bartholomew's Exchange}

The medical system of early modern England was an open one in which people moved from lay to medical expertise very easily. Physicians might write medical books for a popular audience, but they were not averse to learning about remedies from lay people-in a sense treating them as experts. Dr John Symcotts (1592?-1662) used remedies garnered from Lady Alston, Lady St Albans, Lady Harvey, Lady Luke, etc., and from "My sister Symcotts", "My brother Robert", and "My Brother Thomas". ${ }^{60}$ Class was no bar. Symcotts reported the case of a patient suffering from a "purpuric condition during pregnancy": "A beggar woman told the patient that she would recover if she took shepherd's purse in her broth. Hence I ordered her a broth of plantain, periwinkle, shepherd's purse etc." 61 Symcotts used the remedy again in another case. He was not hostile to lay expertise and gave it credit, as when he wrote of the case of Goodwife Viccar of Sutton, "stricken with a palsy all one side ... a woman gave her counsel to be close covered with 2 large sheep skins new taken off for 24 hours together. She endured 17 hours . . . and so was recovered"62

The gravest illnesses were envisaged as candidates for lay treatment. The large number of popular medical books published in the seventeenth century, although often written by physicians, gave detailed advice on how the public could treat serious illness. Although the reader might be warned that consulting a physician was best, the lack of means to pay for one, the distance from one, and the fact that medical skill was one of the attributes of an accomplished lady were given as reasons for publishing the advice. Yet many consulted physicians or surgeons-Pepys often did-and lay cure was frequently described with one eye to its sanction by the experts. Mrs Elizabeth Walker, whose "holy life" was set down by her husband, looked after sick neighbours as well as her husband:

She had a competent measure both in physic and chyrurgery, which she attained with no small industry and labour and increased by experience. Her first and main stock she acquired from a brother in law and very able doctor of the London College ... and was very freely communicative ... and directed her what methods to proceed in for most common diseases, into which her poor neighbours might be incident, and she was very inquisitive of other doctors and had many books, Riverius, Culpepper, Bonettus etc. which she read... and good store of vomits, purges, sudorificks, cordials, pectorals. $^{63}$

The two systems of community and expert care were intertwined right across English society from the poor to the rich. There is no further space to go into detail to demonstrate this, but if I am right, where does the parish, and its possible analogue the hospital, stand? Is parish and hospital care of the sick poor an anomaly in the seventeenth century, something that contrasts with family, neighbourly, and community care, and which, as it grew, would exchange "good" humane family care for the anonymity, and alienation of the institutional incarceration of populus and industrialized England?

${ }^{60}$ F. N. L. Poynter and W. J. Bishop, A seventeenth-century doctor and his patients: John Symcotts, 1592-1622 (Bedfordshire Historical Record Society vol. 31, 1950), introduction, p. xxi.

${ }^{61}$ Ibid.,

62 Ibid.

${ }^{63}$ A. Walker, The holy life of Mrs. Elizabeth Walker, London, 1690, 177-8. 
A way of seeing institutional care of the sick (whether in parishes or hospitals) in this period and freeing it a little from its repressive label is to make the point that nursing-homes, small hospitals or "ill-houses" (like seventeenth- and eighteenthcentury mad-houses) ${ }^{64}$ were dotted around England. They were not repositories for the poor but places where particular groups of patients went. Thomas Brockbank was cared for in a nurse's home when taken ill with smallpox as a student at Oxford in 1691, and then he recuperated in different lodgings:

I sent for my apothecary Hopkins and he told me the smallpox were appearing on my face. I desir'd him to get a nurse for me which he did; and he accompanied me to her house ... I grew very ill and not very sensible in the evening Sir Teasdale etc came to see me and immediately sent for Dr. Frie. ${ }^{65}$

As he recovered, he wrote:

I was removed from my old quarters (widow Tipler's in Coach and Horses lane) to Henry Clinches in St. Clements for airing [a change of air was an important part of recovery from illness] where I stayed 1 month at $12 /$ - the week. Here I purged and was cleans'd and lay on great expenses. ${ }^{66}$

A surgeon, Josias Nicholes of Deal in Kent, had a private hospital separate from his house in the late seventeenth century, "a hospitall for sick and wounded seamen" with twenty-three beds. ${ }^{67}$ The London surgeon, Richard Wiseman, often had patients who came from outside London for treatment, especially his venereal patients for whom the treatment by salivation (using mercury) needed time and caution. It was quite usual for the patient to take lodgings nearby. One "woman of about 50 years of age, of an ill habit of body ... was brought to me ... She importuned me to put her in a course of salivation by unction, and took a lodging near me". ${ }^{68}$ Wiseman wrote that, in general,

Your patient ought to lodge near your house in a close warm chamber. If the season be cold the windows must be covered with blankets and the bed near the fire, and incompassed with a screen if the chamber be large. You ought also to have a strong healthy nurse, such as hath been accustomed to the employment, that she may in the absence of the chirurgeon know how to wash the patient's mouth and direct and encourage him in such rules as may be necessary in the time of salivating. ${ }^{69}$

Sometimes the patient stayed in the home of a medical man. One patient of Wiseman's lodged in an apothecary's house, and the apothecary invited Wiseman and

\footnotetext{
${ }^{64}$ A. Fessler, 'The management of lunacy in seventeenth-century England: an investigation of Quarter Sessions records', Proc. Roy. Soc. Med., Section of the History of Medicine 1956, 49: 901-7; William Parry-Jones, The trade in lunacy: a study of private madhouses in England in the eighteenth and nineteenth centuries, London, Routledge \& Kegan Paul, 1972.

${ }^{65}$ Thomas Brockbank, The diary and letter book of the Rev. Thomas Brockbank 1671-1709, ed. R. Trappes-Lomax, Manchester, Chetham Society, 1930, 36-7.

66 Ibid., p. 39.

${ }^{67}$ Kent Archives Office, Canterbury Consistory Court. Probate inventories, PRC/27/33/160. I am grateful to Dr Richard Palmer of the Wellcome Institute for the History of Medicine for the information.

${ }^{68}$ Richard Wiseman, Several chirurgicall treatises, London, 1676, book 7: 48.

69 Ibid., 11
} 
a physician to undertake his cure. In another case, "A man about 34 years old of a full body came to London and lodged himself and wife in the house of his physician, he being indisposed with an inflammation of his belly to his left groin". 70

Clearly, although many illnesses and deaths happened at home, some took place in other people's homes where the patient had gone for cure. In the London parish of St Lawrence Jewry, the burial register noted the death in 1599 of "Julian Hopkins, a sojourner, lying at physic at Mr. Bratchs girdler". 71

The needs of special groups like soldiers, sailors, travellers, young migrants, and seekers of specialized medical care in the metropolis could all be catered for in places that were like homes but which, in a functional sense, could also be seen as embryonic hospitals. The poor also had recourse, as I have pointed out, to this type of care and perhaps provided it on an organized basis. The parish clerk's memorandum book of the London parish of St Botolph without Aldgate has been uniquely preserved, and it gives us more details about parishioners than would normally be available from the registers, vestry or account books. Through this book, in the Social and Economic Study of Medieval London project, run by the Institute of Historical Research and the Museum of London, the activities have been traced of a woman known variously as "Ellen Wright", "Mother Wright", and "a widow", who from at least 1588 to 1599 was taking sick people and pregnant women into her house. ${ }^{72}$ In 1588 , a stillborn child, whose father came from Pembridge in Hertfordshire, was "born in the house of Ellen Wright, a widow dwelling in taynter yard"; 73 in 1589 , was christened Rose Saunders, whose father was "John Saunders, basket maker, dwelling within the house with Mother Wright" (he died of the flux in 1599 at Widow Wright's, so he was probably a lodger or relative) ${ }^{74}$ Katherine Melton, whose father Thomas was a "sailor", was "born in the house of Mother Wright" in $1589 .{ }^{75}$ In the next year, the daughter of Richard Graves "a musician dwelling in the parish of St. Ollifes in Hart Street" was stillborn- "This child being by him begotten of the body of a single woman named Marie Linch who was sometimes his servant and now lying at the house of Hellen Wright . ..".76 Ellen Wright took in sick people, for in 1598 we read of "Thomas Evered of Bromfield in Essex gent being a bachelor who being troubled with a desease or cancer in his mouth called 'Nolie me tangere' and lying at the house of Ellen Wryght a widow... where he died. Aged 60."77 The daughter of Henry Wootton, "a serving man" and another stranger to the parish, was still born in 1598: her mother "Isabell Wootton was delivered of said child in the house of Ellen Wright ...".78

\footnotetext{
${ }^{70}$ Ibid., 26, 27. In the second case Wiseman added, "pretending he had over-heated his body by disorder in drinking".

${ }^{71}$ The Register of St Lawrence Jewry, London, 1538-1676, transcr. and ed. by A. W. Hughes-Clarke, London, Harleian Society, 1940, vol. 70, pt 1: 130.

72 I am very grateful to Dr Derek Keene, the director of the project, for allowing me to use his material, and also to Dr Martha Carlin for her help.

${ }_{73}$ Parish Clerks Memorandum Book for St. Botolph's (microfilm in Guildhall Library), 17 December. 1588.

74 Ibid, 12 October 1589; 8 February 1599.

75 Ibid, 7 January 1589.

76 Ibid, 10 November 1590.

77 Ibid, 19 December 1598.

${ }^{78}$ Ibid, 26 February 1598.
} 
Ellen Wright clearly took in outsiders whose occupations, or those of their mates, placed them in the lower ranks of society. We know of her activities only when there was a death, birth or stillbirth in her house, and she may well have had many clients unknown to us. In any case, she clearly built up a reputation and people were sent to her house when being treated or recuperating. In 1599:

John Akenhead a tapster late dwelling at the sign of the greyhound in Southwalk who for some desease was to be cured by one Mr. Foster a chirurgian and did lie [was lodged at] at the house of Ellen Wryght a widow ... where he died . . years 25 ... de morbo gallico [of syphilis]. ${ }^{79}$

If the above reminds one of Wiseman's patients, the next one has similarities with that of Thomas Brockbank-Humphrey Page died of consumption and was buried on 8 July 1599. He was:

Citizen and haberdasher of London whose dwelling was in St. Sweethins Lane in London who being a bachelor and being sick in hope to recover his health by changing the air [a typical treatment for consumption] was lodged at the house of Ellen Wryght a widow dwelling in a garden house. [Ellen Wryght's house was in a green and wooded part of the parish, ideal for good air] . . Aged $25 .{ }^{80}$

There were clear inequalites in the care of the sick across society-one has only to remember how plague nurses came to be feared when the better-off were locked up in their houses and given a taste of the parish care that the poor habitually faced. ${ }^{81}$ Nevertheless, health care, when seen in structural, if not in social, terms, appears similar for both rich and poor. Both had recourse to lay and to expert help in terms of treatment, care, and lodging. A certain degree of neighbourly, family-type care was given by the poor to one another, if on a commercial basis. Conversely, commercial, small-scale institutional care was not limited to the poor but was used by a large section of the population-not surprising in an England where relatively small nuclear families and population mobility were common. There is a slithering, ambiguous, and flexible scale running from the care of the sick in families to the care of the sick poor by parishes and institutions in which the same structural elements express themselves at different points along it. The easy dichotomies produced up to now by historians will have to be altered.

\section{APPENDIX: THE RUMNEY FAMILY}

Philip Rumney was a plasterer. "Goody" (possibly Margaret) Rumney was his wife, and Katharine (or Katherine) their daughter. In the following, "Ac."signifies the Account Books (note 3 above) and "v.", vol. 2 of the Vestry Minute Books (note 2 above), with the page numbers.

1647 Phillip: Pension five shillings per week; and, "at several times being in want and sick-18s." (Ac. 133; v.22)

1650 "Paid for Margaret Rumney before she went to Bethlem and since she came from thence with money for clothes and other thing in her sickness" $-£ 11.3 s$. (This could be Goody

\footnotetext{
${ }^{79}$ Quoted by Forbes, op. cit., note 13 above, p. 92.

80 Memorandum Book, 8.July, 1599.

81 Of course, most of the well-to-do would have been able to afford to leave London at times of plague, and the sums given by St Bartholomew's to support well-off parishioners were quite high.
} 
Rumney.) "Margaret Rumney in Bethlem Hospital 5/- [per week] . . £13.0.0". (Ac. $141 ;$ v. 30,35 )

Goody: "Allowed her by reason of sickness and other poor people of this parish£4.4.0."

Phillip is made parish beadle, on probation. (Ac. 141; v. 30, 35)

1651 Phillip's rent is paid for a year: $£ 2$.

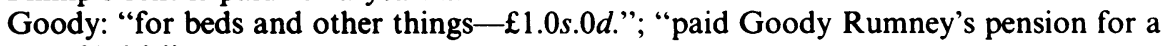
year £1.6.0."

Katharine: "Paid Goody Rumney 3/-a week for her daughter $£ 7.16 .0 "$. (v. 37, Ac. 144)

1652 Phillip: "Pension at $2 s$. per month and $4 s$. per month for 9 months- $\_2.4 .0$."

Katharine; "Paid Rumney for his daughter besides his pension at several times $18 s$." (Ac. 146)

1653 Phillip and Katharine: "Phillip Rumney being aged and his daughter distracted"-a pension of $£ 2.12 s$.

Katharine: "Rumney's daughter being distracted, ordered to be carried to bedlam for her cure at the parish charge".

Among "Monies given to the poor in their sickness"; $2 s .6 d$. to Rumney's wife.

Katharine: "To a nurse for keeping Rumney's daughter 15 days--5s.6d."; "To Rumney and his daughter being mad January 6th-6s.0d". "To Rumney $2 / 6$ February 19th".

Goody: for nursing a foundling for 9 days-three shillings.

Katharine: "Paid and spent on the mad doctor for Rumney's daughter-1s.0d." (v.47, 48; Ac. 149, 150)

1654 Goody: "paid to the nurse for three weeks' keeping of Goody Rumney-9s.0d. Paid to the searchers and charges for her burial-15s.8d."

Katharine: "For a bond warrant and other charges to get Rumney's daughter into Bethlem-6s.6d. For keeping her there 18 weeks and 3 days at $5 s .0 d$. per week£4.12s.0. Paid and spent in getting her out thence-1s.8d." (Ac. 152)

1655 To Phillip, a pension of $£ 1.6 s$.

Katharine: "for her relief this year- $-£ 1.4 s .6 d$."; "Paid at a meeting about Katharine Rumney-8d." (Ac. 154, 156). Vestry minutes have her in Bedlam (v. 52), and the churchwarden is ordered to relieve her as occasion serves (v. 55).

1656 Philip: "old Rumney was voted out of the warder's place" and he receives a pension and relief totalling $£ 2.19 \mathrm{~s} .6 \mathrm{~d}$. that year.

Katharine: "paid for Katharine Rumney's going to Ware [a place where foundlings were nursed]-3s.0d. For a pair of shoes for her-2s.6d. For four months there$£ 2.8 s .0 d$. For coming home $-4 s .10 d$. and more given her for her relief and attending her father- $£ 2.10 \mathrm{~s} .6 \mathrm{~d}$. [total] $-£ 5.8 \mathrm{~s} .10 \mathrm{~d}$." She is given a pension of four shillings and noted as "distrat" in the vestry minutes.- $£ 10.8 s .0 d$. (highest by far)

Phillip: Widow hall (pensioner) and Nurse Pelter are given, "for their attendance on Goodman Rumney and Widow Bullin in their sickness- $£ 6.5 s .6 d$."; "Paid Widow Shorey for her relief-14s.6d. and for physick for her and Wells and Rumney in their sickness-20s.0d". (Ac. 157, 158: v, 57, 59)

1657 Phillip: "monthly pension for a year $£ 1.6 s .0$ d."; "Paid Mr Evans plasterer for mending Rumney's house and their vault emptying. $£ 00.16 .08 d$."

Phillip and Katharine: "their weekly pension for a year- $£ 9.2 s .0 d$."; "It was ordered that I [churchwarden] should pay what I think fit towards the maintenance of Goodman Rumney and his daughter."

Katharine: "Given old Rumney's daughter in her sickness-2s.0d." (Ac. 160, 161; v. 61)

1658 Phillip dies: "Paid nurse that tended Goody Rumney in his sickness-8s.0d."

Mr. Beale (later one of the poor) petitions successfully to be the tenant of Rumney's house at $£ 3$ per annum. The house, which belonged to the parish, to be repaired at its expense: $\mathfrak{f 1 . 3 s . ( v . 6 6 )}$ 


\section{Andrew Wear}

Katharine petitions at the vestry for maintenance and is given two shilings a month ( $\mathrm{v}$. 66 ), as well as $2 s .6 d$. to buy shoes. "Paid a joiner that removed Katharine Rumney's goods and set them up-3s.0d." (Ac. 163; v. 66)

1659 Katharine: " 3 months' pension at $2 s .-6 s .0 d$. 8 weeks' allowance besides at $12 d .-8 s .0 d$ For 17 weeks' pension at $18 d$. before sent Bedlam- $£ 1.5 s .6 d$. For necessaries and people to watch her and other expenses before she could be admitted- $-£ 1.6 \mathrm{~s} .0 \mathrm{~d}$. . . . For a bond and warrant $-6 s .0 d$. For carrying her to Bedlam and given the keepers-5s.6d. Paid William Godbie, Steward of Bedlam, for 21 weeks and 6 days for her keeping there at $5 s$. per week- $£ 5.9 s .6 d$. For a Bedlam gown, petticoats, waiscoats, neckcloths, shifts, porter etc. $-£ 1.1 s .6 d$. For a pair of hose and shoes- $4 s .6 d$. For necessaries weekly after she came out of Bedlam-16s.6d." (Ac. 167)

1660 To Katharine; a pension of $18 d$. per week- $£ 3.18 s .0 d$. (Widow Hasard's pension was two shillings per week) "To Susan Chandler and Margaret Ralsey for helping Katharine Rumney-6s.6d. [Ralsey was a pensioner, Chandler one of the poor.] To Mr Thicknes for Katharine Rumney -13s.6d. To [Katharine] at several times by order-£1.6s.0d." (Ac. 170)

1661 To Katharine, a pension totalling $£ 3.18 s$. (Ac. 173)

1662 To Katharine; 16 weeks' pension at $18 d$. per week- $£ 1.4 s$. "Paid and spent in getting Katharine Rumney in Bethlem and for a warrant and bond, and other charges-14s.9d. To Goodman Wells for looking to her 3 nights and days, meat and drink-8s.9d. and to Margaret Ralsey for looking to her 3 weeks-5s.0d." and "for 23 weeks and 2 days at $5 s$. per week in Bedlam-£5.16s.6d."; "Spent at several times for looking after Katharine Rumney, for washing her linen and other charges at Bedlam House at her coming forth-14s.10d."; "Paid for 3 yards $3 / 4$ of cloth for Katharine Rumney to make her

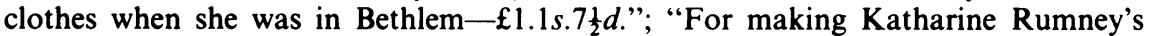
clothes $\mathfrak{E 0 . 1 0 . 0 . "}$

"Paid Katharine Rumney for 13 weeks pension from Christmas to Our Lady Day she being very weak and ill new come forth of Bethlem $2 s .6 d$. per week-£1.12s.6d. For sweeping the chimneys of Goody Hazard and Katharine Rumney-1s.0d. Paid Katharine Rumney's scores at Bendalls and Parsons at several times before she went to Bethlem-7s.91 d." [Parsons was one of the poor; she became a searcher and her husband was a pensioner] (Ac. 176, 177)

1663 To Katharine; a pension totaling $£ 6.8 s$. for the year. (Ac. 180)

1664 To Katharine; a pension of $£ 6.10$ s. "Paid to her [Susan Chandler] and several others for looking to Katharine Rumney f0.6.0" (Ac. 183, 184)

1665 To Katharine; a pension, totalling £5.10s. (Ac. 187)

1666, 1667 To Katharine; a pension totalling $£ 13$. (Susan Chandler and Margaret Ralsey receive $£ 2.12 s$. and $£ 4.18 s$. respectively). (Ac. 191).

1668, 1669 "Paid Katharine Rumney’s rent £2.0.0”; "Paid for Katharine Rumney’s shoes £0.5.0” (Ac. 192).

1670 To Katharine; a pension totaling $£ 6.10$ s. (Ac. 194)

1671 "Paid Katharine Rumney for letting her blood 10s.6d."; a pension totalling f6.10s. "Paid more to Katharine Rumney 4/6". (Ac. 195)

1672-3 "Paid for [Katharine's] rent 5s.0d."; a weekly pension at $2 s .6 d$. per week for 4 weeks-ten shillings. Eight weeks' pension at $4 s .6 d$. per week "when she lay sick$£ 1.16 s .0 d$. Paid for a pair of sheets and a shift for her-10s.0d. Given her nurse $6 d$. Paid for a coffin for her 7s.0d. Paid for an apothecary for physick for her $2 s .0 d$." 